\title{
Using an Outcome-Based Information Technology Curriculum and an E-Learning Platform to Facilitate Student Learning
}

\author{
Azzedine Lansari and \\ Abdallah Tubaishat \\ College of Information Technology, \\ Zayed University, Abu Dhabi, UAE
}

azzedine.lansari@zu.ac.ae

abdallah.tubaishat@zu.ac.ae

\author{
Akram Al-Rawi \\ College of CS \& IT, \\ King Faisal University, \\ Al-Hassa, Saudi Arabia \\ aalrawi@kfu.edu.sa
}

\begin{abstract}
A recently established university in the United Arab Emirates has shifted from an input-based teaching model to an outcome-based learning model. The outcome based academic model is new in the Gulf region and is designed to allow students and faculty members to work together to foster learning. This model is a dramatic departure from the traditional input model where students in the Gulf have learned to mainly accept and retain information. Using the university's learning outcomes model, the College of Information Technology (CIT) has identified five learning outcomes and used them to develop its curriculum. All learning outcomes are integrated into all CIT courses. All students own a laptop and have wired and wireless access to various university resources such as the library, Blackboard, IT labs and the Internet. Currently, the CIT is moving to a web-based learning environment. Under this environment, the outcome-based academic model requires faculty members to shift their efforts from teaching or lecturing to facilitating student learning. CIT faculty are reshaping their course contents and refocusing their courses to clearly show all the steps needed to learn various concepts and skills as well as how students can achieve a particular learning outcome. This study proposes an outcome-based IT curriculum for delivery in an e-learning environment. Such an environment is ideal for female students who prefer to have limited interaction with male faculty and who typically need more time to understand IT concepts in English. It is anticipated that this e-learning environment will facilitate the delivery of course content and also improve the discussion and communication between students and faculty.
\end{abstract}

Keywords: Outcome-based learning environment, e-learning, synchronous and asynchronous learning, learning management systems.

Material published as part of this publication, either on-line or in print, is copyrighted by the Informing Science Institute. Permission to make digital or paper copy of part or all of these works for personal or classroom use is granted without fee provided that the copies are not made or distributed for profit or commercial advantage AND that copies 1) bear this notice in full and 2) give the full citation on the first page. It is permissible to abstract these works so long as credit is given. To copy in all other cases or to republish or to post on a server or to redistribute to lists requires specific permission and payment of a fee. Contact Publisher@InformingScience.org to request redistribution permission.

\section{Introduction}

Universities in the USA and worldwide are taking a critical look at their educational systems. A recent US national panel (Greater expectations report, 2002) calls for a dramatic reorganization of undergraduate education to ensure that all college students receive not just access to college, but an education of 
lasting value. The report also recommends colleges to help students become "intentional" life long learners, and to create new assessments that require students to apply their learning to the real world. In an effort to shift the focus from the traditional teaching/lecture style to a student centered learning style, a number of academic institutions in the USA have moved to an outcomebased education framework. Outcome-based education is a method of teaching that focuses on what students can actually do after they are taught (Bouslama, Lansari, Al-Rawi, \& Abonamah, 2003). All curriculum and teaching decisions are made based on how best to facilitate the desired outcome. This leads to a planning process that is different from the traditional educational planning. The desired outcome is first identified and the curriculum is created to support the intended outcome (Furman, 1994). Furthermore, advances in networking technologies and the Internet have dramatically impacted teaching and learning in higher education (Hodges, 2004; Muhlhauser and Trompler, 2002; Smith \& Winking-Diaz, 2004). E-learning has become very popular in the last decade and now impacts learners of all ages. E-learning may be defined as "the delivery of education through various electronic media, and in a broader context it may also be defined as the effective use of technology to meet society's needs for learning (Cohen, \& Nycz, 2006).

In a technology-mediated learning environment, students and teachers use a wide range of information and communication tools (ICT) to communicate, collaborate and share resources. These tools provide anytime-anywhere learning opportunities. Web-based learning (WBL) has become a major trend in teaching and learning. Universities worldwide are offering access to a number of their courses on the Web. Some universities have produced reusable Web-based multimedia presentations. Currently, various tools can be easily used by authors to record and encode streams of audio and video and then integrate them in multimedia materials such as PowerPoint slides (Bodendorf, Schertler, \& Cohen, 2005).

There are two major classes for web based learning systems: synchronous and asynchronous (Kinshuk \& Young, 2003; Neubauer \& Lobel, 2003). Synchronous WBL systems are used to create a virtual classroom environment where all students are accessing the same information. Computer Supported Collaborative Work (CSCW) systems, on the other hand, are asynchronous in nature and designed to replace physical classrooms with the virtual ones (Litiu, 2003; Marsic, Dorohoceanu, \& Tremaine, 2002). Most commonly available WBL systems are asynchronous in nature. In these systems, a web server hosts course contents and other teaching materials. Learners have access to this material at anytime from anywhere using any web-browser (Linge, 2003). Currently, all Zayed University (ZU) courses are implemented using a WBL system. In technology mediated learning environment systems, the following factors contribute to effective online learning: using relevant and challenging assignments, having coordinated learning environment, adequate and timely feedback from instructors, developing rich environments for student-tostudent interaction, flexibility in teaching and learning. In a good technology mediated learning system, students must be able to read, critically reflect, discuss, argue, generate and present new interpretations, share and exchange information ideas.

Traditional as well as completely online learning environments each have their own limitations. A hybrid approach that combines traditional teaching with online learning could provide the best of both worlds. Many universities around the world are experimenting with online course-building shells, such as Blackboard and WebCT to help create learning communities. Burge (1995) states that in a technology-mediated learning environment, instructors are asked to articulate more clearly their goals and methods to the development team members. Students are also asked to take more responsibility for their learning. In their study on learners' perceptions toward the Webbased distance learning activities/assignment portion, Koohang and Durante (Koohang \& Durante, 2003) found that regardless of age or gender, students perceived that the Web-based learning activities/assignments portion of their hybrid program promoted learning. However, the stu- 
dents' experiences using the Internet were very significant, indicating that the success of Webbased instruction may depend on increased experience with the Internet.

The goal of this study is to show how an outcome-based Information Technology curriculum coupled with a technology mediated learning environment is used to facilitate the delivery of IT courses in an all female academic environment. The rest of the paper is organized as follows: first it introduces the technology mediated learning environment at $\mathrm{ZU}$; followed by an introduction to the outcome-based academic model; then it introduces the IT College curriculum and its learning outcomes; the next section shows the development of master course syllabi with the integration of learning outcomes to be used in an e-learning environment; the final section is the conclusion.

\section{Technology Mediated Learning Environment at Zayed University}

ZU is a recently established academic institution located in the United Arab Emirates (UAE). ZU is the first institution in the Gulf region to pursue the idea of a laptop-based learning environment. It is actually known as the laptop university in the region. As a young institution, ZU has had the opportunity to build upon the best traditions in higher education. The university is provides a western style higher education to local female students of the United Arab Emirates. The University has five colleges and most of the faculty members are western educated. Its faculty endeavor to provide students learning opportunities in an American style of teaching ensuring a very high quality of education.

ZU has an excellent technology infrastructure. ZU campuses are fully networked and allow students to connect to the university network and Internet from anywhere on campus. The whole university has a wired and wireless internet access. Each student is required to purchase a recent laptop for use on and off campus. Each faculty member receives a laptop with a two-year replacement schedule.

Students have a wealth of technology available to assist them in the learning process. In the CIT College, all students have their own laptop and it is loaded with software that can be used to help them complete their work independently without coming to their campus after hours. The CIT college has an independent network infrastructure for teaching and research, in addition to the University network. This infrastructure allows students to login remotely into Linux servers to use tools needed for programming languages, databases, and web development related courses. Students can also use Linux-based communication tools to collaborate with each other and with instructors. All ZU courses are implemented on Blackboard, a learning management system. ZU students can access Blackboard from anywhere at anytime using a web client.

\section{The ZU Outcome-Based Academic Program Model}

$\mathrm{ZU}$ has recently adopted an outcome based learning framework. ZU has a strong focus on the students' learning outcomes to improve both curriculum and learning practices. The Academic Program Model (APM) (The Academic Program Model, 2006) developed by faculty, emphasizes on a commitment to learner-based education and to a shift in the paradigm from teaching to learning. This model focuses on what students can actually do after they graduate. More detail about this model can be found in Internal Report on Self-Assessment of ZU Based on Accreditation Standards of the Middle States Commission on Higher Education, 2006; and the Academic Program Model, 2006.

The ZU academic program model is a hybrid approach that can accommodate learning outcomes to measure the learning process and uses grades to accommodate the classic academic system 4 . The College of Information Technology (IT) has developed a curriculum based on the academic 
program model and driven by a set of well-chosen learning outcomes. This curriculum is designed to reflect the UAE needs for graduates that are well prepared to enter the workforce and to assume their place of responsibility in the nation. The goal of the College is to produce graduates having strong technology and communication skills as well as a good understanding of business practices and work ethics.

The purpose of the outcome based model is to provide students a focused and coherent academic program and to prepare our graduate students for a rapidly changing and unpredictable future. The framework that constitutes the academic model is composed of three components (The Academic Program Model, 2006):

- Readiness program to ensure that students are competent in English language

- General Education

- Degree Majors

A major objective of the undergraduate experience at $\mathrm{ZU}$ is the development of the skills necessary for continuous life long learning. The Academic Program Model is designed to help achieve this objective by providing students with a foundation and framework for all university studies. Every ZU course focuses on one or more of the six university-specified learning outcomes. The learning outcomes are incorporated into normal course work, and therefore are an integral part of disciplinary content and evaluation of the course. Threaded throughout the baccalaureate curriculum, the learning outcomes help students achieve a higher order of intellectual development. ZU has the following graduation requirements for all students regardless of their major (The Academic Program Model, 2006):

- Information Literacy and Communication: ZU graduates will be able to recognize information needs, access and evaluate appropriate information to answer those needs, and communicate effectively to a variety of audiences in both English and Arabic.

- Information Technology: ZU graduates will be cortically aware of the implications of information technology on the individual and on society, and be able to use IT to communicate and solve problems in an ethical way.

- Critical Thinking and Quantitative Reasoning: ZU graduates will be able to use information, reasoning, and creative processes to achieve goals and make responsible decisions.

- Global Awareness: ZU graduates will be able to relate to communities beyond the local, perceive and react to differences from an informal and reasoned point of view, and be critically aware of the implications and benefits of cultural interaction.

- Teamwork and leadership: ZU graduates will be able to work efficiently and effectively in a group. ZU graduates will be able to assume leadership roles and responsibilities in a variety of life situations and accept accountability for the results.

- Bilingual: ZU graduates will be able to communicate effectively (orally and in writing) in both English and Arabic

The CIT College has established five learning outcomes that complement the learning outcomes of the ZU Program Academic Model. These major learning outcomes form the basis for analysis and assessment that play an essential role in the continuous process of improvement. The major learning outcomes of the CIT College are as follows:

- Problem Identification and Analysis: CIT graduates will be able to organize, define, and classify problems. 
- Problem Solving: CIT graduates will derive solutions and evaluate their success.

- Information Technology and their Application and Managements: CIT graduates will understand the capabilities, use, and application of information technologies.

- Systems Principles and Practices: CIT graduates will demonstrate understanding of system types, structure, standards, and metrics.

- Technical Communication: CIT graduates will organize, develop, present, and evaluate technical material.

\section{Outcome-Based Information Technology Curriculum}

The academic program of the CIT College is practical; competency based, and designed to prepare students for entry-level positions as information technology professionals. A program of study in the CIT College includes general courses, core courses, and major or concentration courses. Currently, the CIT College offers a Bachelor of Science (BS) degree in Information Technology with three concentrations: Information Security, Network Technologies, and Web Technologies. Figure 1 shows a list of all the core courses in the IT curriculum as well as courses for each of the three concentrations.
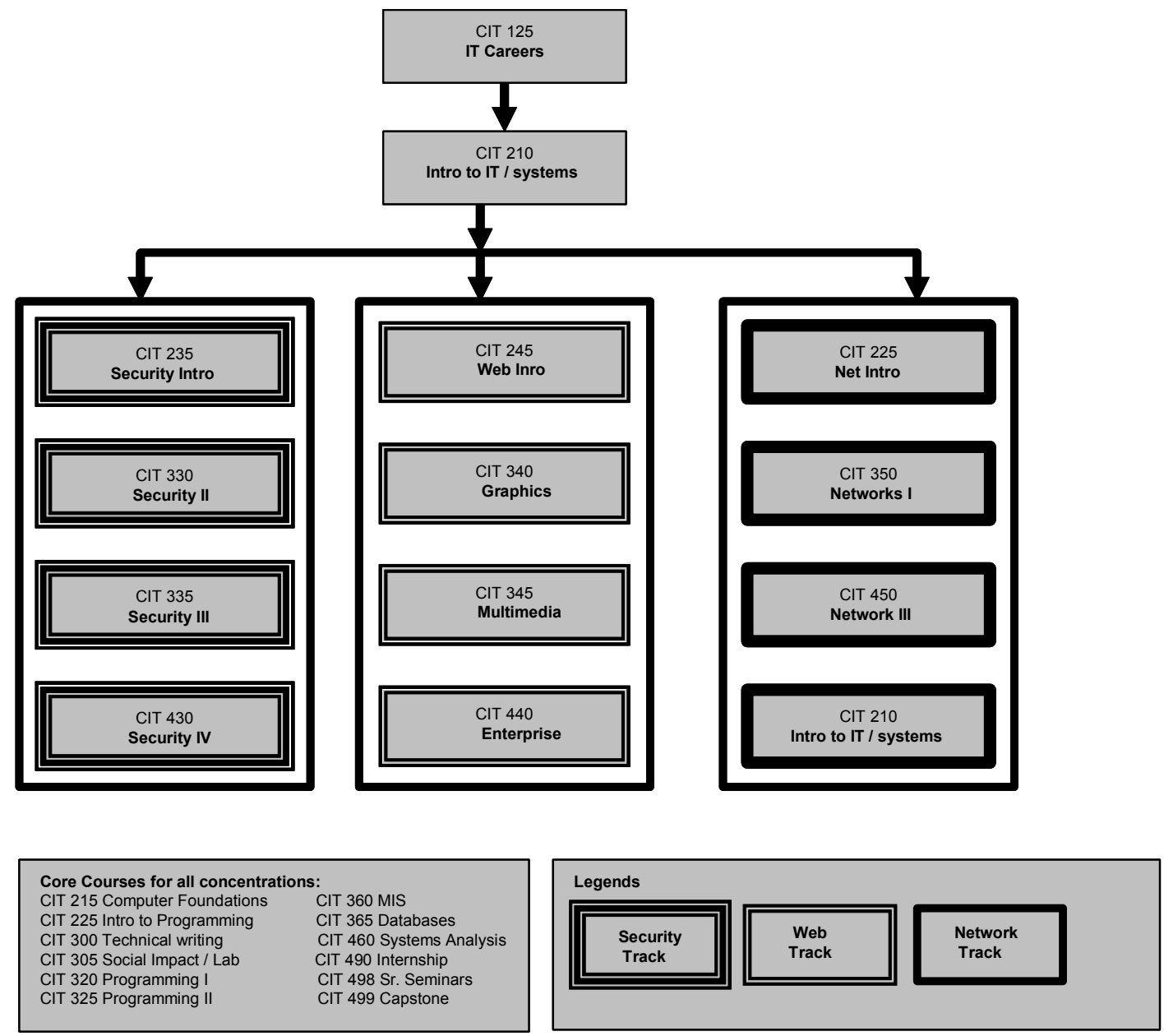

Figure 1: Information Technology Curriculum 
The CIT College uses both types of learning outcomes in its curriculum: ZU Learning Outcomes (ZULOs), and Major Learning Outcomes (MALOs). The role of the ZULOs in the academic program is critical as it provides a starting point for the college outcome-based program. It provides students with an understanding of the meaning of learning outcomes and the role they play in the student's plan of studies. The ZULOs/MALOs matrix shown in Table 1 is a framework that defines the relationship between ZULOs, MALOs and the CIT curriculum. The main objective of the matrix is to show ZULOs and MALOs are addressed in the CIT curriculum. Moreover, the matrix provides critical information about the required level of exposure to various learning outcomes throughout the student's academic life.

The matrix shows for each IT course which learning outcomes are addressed and what is the potential achievement. This defines the possible exposure to various learning outcomes provided by each course. Upon completion of their academic program students will have been provided with a number of opportunities to show evidence of the achievement of all learning outcomes. All students need to keep evidence of learning outcome achievement in an e-portfolio. It is to be noted that the matrix has been developed by CIT faculty over the past few years. Now that the ZULO/MALOs matrix has been established, the college assessment plan can move forward. The student e-portfolio which contains sample pieces of evidence will form the basis for the college assessment plan. Table 1 lists all CIT courses and their respective learning outcomes with their associated levels of achievement.

Table 1: Learning Outcomes in IT College

\begin{tabular}{|c|c|c|c|c|c|c|c|c|c|c|c|c|c|}
\hline & & & \multicolumn{6}{|c|}{ ZULOs } & \multicolumn{5}{|c|}{ MALOs } \\
\hline & & & IT & GA & CTQR & ILC & TL & BL & PIA & PS & ITA & STP & $\mathbf{T C}$ \\
\hline 1 & CIT 125 & Discovering IT & $\mathrm{B}$ & B & & B & & & & B & B & & $\mathrm{B}$ \\
\hline 2 & CIT 210 & $\begin{array}{l}\text { Intro. to IT and Sys- } \\
\text { tems }\end{array}$ & B & & B & B & B & $\mathrm{BL}$ & B & B & B & B & B \\
\hline 3 & CIT 215 & Comp. Foundations & & & $\mathrm{D}$ & & & & $\mathrm{D}$ & $\mathrm{D}$ & & & \\
\hline 4 & CIT 225 & Intro. Prog/Prob Sol. & $\mathrm{D}$ & & $\mathrm{D}$ & & & & B & B & & & \\
\hline 5 & CIT 235 & Info. Security Basics & $\mathrm{D}$ & B & B & B & & & $\mathrm{D}$ & $\mathrm{D}$ & & & \\
\hline 6 & CIT 245 & Web Development & $\mathrm{D}$ & & & & & & $\mathrm{D}$ & $\mathrm{D}$ & & & $\mathrm{D}$ \\
\hline 7 & CIT 255 & Networks/Telcomms & $\mathrm{A}$ & & & & $\mathrm{D}$ & & & & $\bar{A}$ & & $\mathrm{D}$ \\
\hline 8 & CIT 270 & ICDL & $\mathrm{D}$ & & & & & & & & & & B \\
\hline 9 & CIT 295 & Independent Studies & $\mathrm{A}$ & & & & & & & & $\bar{A}$ & & $\mathrm{D}$ \\
\hline 10 & CIT 300 & $\begin{array}{l}\text { Technical Writing } \\
\text { (English) }\end{array}$ & & & D & D & & & D & & D & & A \\
\hline 11 & CIT 301 & $\begin{array}{l}\text { Technical Writing } \\
\text { (Arabic) }\end{array}$ & $\mathrm{D}$ & $\mathrm{D}$ & & $\mathrm{D}$ & & & $\mathrm{D}$ & & A & & $\mathrm{D}$ \\
\hline 12 & CIT 305 & $\begin{array}{l}\text { IT Local/Global } \\
\text { Cultures }\end{array}$ & $\mathrm{D}$ & A & & D & & $\mathrm{D}$ & D & & $\mathrm{D}$ & & $\mathrm{D}$ \\
\hline 13 & CIT 306 & $\begin{array}{l}\text { IT Local/Global } \\
\text { Cultures (Arabic) }\end{array}$ & $\mathrm{D}$ & D & & D & & & D & & A & & D \\
\hline 14 & CIT 320 & Prog/Prob Sol. I & $\mathrm{D}$ & & $\mathrm{D}$ & & & & $\mathrm{D}$ & $\mathrm{D}$ & & & $\mathrm{D}$ \\
\hline 15 & CIT 325 & Prog/Prob Sol. II & & & $\mathrm{D}$ & & & & A & A & & & \\
\hline 16 & CIT 330 & $\begin{array}{l}\text { Global Information } \\
\text { Security }\end{array}$ & $\mathrm{D}$ & D & B & B & & & & & D & D & D \\
\hline 17 & CIT 335 & $\begin{array}{l}\text { Information Security } \\
\text { Technologies }\end{array}$ & $\mathrm{D}$ & B & D & D & & & D & D & & & \\
\hline
\end{tabular}




\begin{tabular}{|c|c|c|c|c|c|c|c|c|c|c|c|c|}
\hline 18 & CIT 340 & Computer Graphics & A & & A & & & & & A & & \\
\hline 19 & CIT 345 & Multimedia Systems & & & & & $\mathrm{D}$ & $\mathrm{D}$ & $\mathrm{D}$ & & & \\
\hline 20 & CIT 350 & Comm. Networks I & $\mathrm{A}$ & & & & $\mathrm{D}$ & & & $\mathrm{A}$ & & $\mathrm{D}$ \\
\hline 21 & CIT 355 & Comm. Networks II & $\mathrm{A}$ & & $\mathrm{D}$ & & $\mathrm{D}$ & & & $\mathrm{A}$ & & \\
\hline 22 & CIT 360 & $\begin{array}{l}\text { Management of } \\
\text { Information Systems }\end{array}$ & A & B & D & & D & D & D & A & $\mathrm{D}$ & \\
\hline 23 & CIT 365 & Database Systems & A & & A & & & $\mathrm{A}$ & A & & & $\mathrm{D}$ \\
\hline 24 & CIT 395 & Independent Studies & A & & & & & & & A & & $\mathrm{D}$ \\
\hline 25 & CIT 430 & $\begin{array}{l}\text { Information Security } \\
\text { Management }\end{array}$ & D & $\mathrm{D}$ & B & D & & & & D & $\mathrm{D}$ & D \\
\hline 26 & CIT 440 & $\begin{array}{l}\text { Enterprise Web Ap- } \\
\text { pl'ns }\end{array}$ & A & & & & & $\mathrm{D}$ & & A & & \\
\hline 27 & CIT 450 & Comm. Networks III & $\bar{A}$ & & $\mathrm{D}$ & & & & & $\mathrm{A}$ & & \\
\hline 28 & CIT 460 & $\begin{array}{l}\text { Sys Analysis \& De- } \\
\text { sign }\end{array}$ & D & & $\mathrm{D}$ & & & $\mathrm{D}$ & & & & A \\
\hline 29 & CIT 470 & Applied Database & $\bar{A}$ & & $\mathrm{~A}$ & & & & A & & & $\mathrm{D}$ \\
\hline 30 & CIT 475 & IT Sys Development & $\mathrm{D}$ & & $\mathrm{D}$ & & & $\mathrm{D}$ & & & & $\mathrm{D}$ \\
\hline 31 & CIT 490 & Internship & $\mathrm{D}$ & & $\mathrm{D}$ & & & & $\mathrm{D}$ & & & $\mathrm{D}$ \\
\hline 32 & CIT 495 & Independent Studies & $\bar{A}$ & & & & & & & $\mathrm{~A}$ & & $\mathrm{D}$ \\
\hline 33 & CIT 497 & Special Topics & $\mathrm{A}$ & & & & & & & $\mathrm{A}$ & $\mathrm{D}$ & \\
\hline 34 & CIT 498 & Senior Seminar & D & & $\mathrm{D}$ & & $\mathrm{D}$ & & $\mathrm{D}$ & & & $\mathrm{D}$ \\
\hline 35 & CIT 499 & Capstone & $\mathrm{A}$ & & $\mathrm{A}$ & $\mathrm{A}$ & $\mathrm{A}$ & $\mathrm{A}$ & $\mathrm{A}$ & $\mathrm{A}$ & & $\mathrm{A}$ \\
\hline
\end{tabular}

\begin{tabular}{|l|l|}
\hline MALOS: & ZULO: \\
PIA - Problem Identification and Analysis & IT - Information Technology \\
PS - Problem Solving & GA - Global Awareness \\
ITAM - Information Technology Applications and Management & CTR - Critical Thinking and Reasoning \\
STP - Systems Theory and Practice & ILC - Information Literacy and Communication \\
TC - Technical Communication & TL - Teamwork and Leadership \\
LEVELS: B - Beginning, D - Developing, A - Accomplished & BL - Bilingual \\
\hline
\end{tabular}

\section{Using Learning Outcomes in Master Syllabi for an E-learning Environment}

The master course syllabus is a critical component that needs to clearly show the integration of all desired learning outcomes into particular courses. A master course syllabus is developed for all IT core courses as well as elective courses. The components of the master course syllabus include course number and title, objectives, topics, learning outcomes, and evidence of learning outcome achievement. The course description is taken from the University course catalogue. The course objectives provide focus on the course content. The course topics are listed to provide guidance and allow coverage of critical components of the course. The University learning outcomes as well as the Major learning outcomes are listed along with the expected level of achievement respective to that course.

The course assessment activities and standards component of the master course syllabus provides information on the in-class activities to test the knowledge and understanding of the course con- 
tent by students. Furthermore, assignments are used to test student's abilities to apply their knowledge and assess their understanding and achievement level of particular learning outcomes.

For example, Table 2 shows that students who take the CIT225 course on programming and problem solving have the potential to achieve the Information Technology (IT) learning outcome at the accomplished (Acc) level. Furthermore, for that particular learning outcome, students can use their work as primary evidence to show their achievement of that particular learning outcome. On the other hand, students taking this course may only achieve a developing (Dev) level for the Critical Thinking and Reasoning (CTR) outcome. For this learning outcome, students may decide to use their work as secondary (temporary) evidence of their achievement.

Table 2: CIT 225 Course Topics Supporting Learning Outcomes

\begin{tabular}{|c|c|c|c|c|c|c|c|c|c|c|}
\hline & \multicolumn{5}{|c|}{ ZU Learning Outcome } & \multicolumn{5}{|c|}{ CIS Learning Outcome } \\
\hline Outcome & IT & GA & CTQR & ILC & TL & PIA & PS & ITA & STP & TC \\
\hline Level & Acc. & & Dev & & & Dev. & Dev. & & & \\
\hline Primary Evidence & $\checkmark$ & & & & & $\checkmark$ & & & & \\
\hline $\begin{array}{l}\text { Secondary Evi- } \\
\text { dence }\end{array}$ & & & $\checkmark$ & & & & $\checkmark$ & & & \\
\hline
\end{tabular}

Table 3 shows that students who take the CIT245 course on Web Development have the potential to achieve the Information Technology (IT) learning outcome of the ZU learning outcomes at the developing level. Furthermore, for that particular learning outcome, students can use their work as primary evidence. The rest of the ZU learning outcomes are not addressed in this course. On the other hand, students taking this course may achieve three MALOs at the developing level, which are the PIA, PS and TC. For these MALOs, students may decide to use their work as primary or secondary evidence of their achievement. Primary evidence means that the assignment is significant enough to stand alone in the student e-portfolio as evidence for the achievement of the learning outcome. For example a major course project would qualify as primary evidence.

Table 3: CIT 245 Course Topics Supporting Learning Outcomes

\begin{tabular}{|c|c|c|c|c|c|c|c|c|c|c|}
\hline & \multicolumn{5}{|c|}{ ZU Learning Outcome } & \multicolumn{5}{|c|}{ CIS Learning Outcome } \\
\hline Outcome & IT & GA & CTQR & IL\&C & TL & PIA & PS & ITA & STP & TC \\
\hline Level & Dev. & & & & & Dev. & Dev. & & & Dev. \\
\hline $\begin{array}{l}\text { Primary Evi- } \\
\text { dence }\end{array}$ & $\checkmark$ & & & & & $\checkmark$ & & & & $\checkmark$ \\
\hline $\begin{array}{l}\text { Secondary Evi- } \\
\text { dence }\end{array}$ & & & & & & & $\checkmark$ & & & \\
\hline
\end{tabular}

The course assessment activities and standards component of the master course syllabus provides information on the in-class activities to test the knowledge and understanding of the course content by students. Furthermore, assignments are used to test student's abilities to apply their knowledge. 
The final component of the master course syllabus specifies the rationale that supports the achievement of the learning outcomes. For example, Table 4 shows the course objectives that support the learning outcomes for the CIT 245 course. For instance the rationale for the IT ZULO states that: "Students learn new skills for developing websites and web-based applications using HTML, DHTML and XML" which supports the IT learning outcome.

Table 4: Course Topics Supporting Learning Outcomes

\begin{tabular}{|c|l|}
\hline $\begin{array}{c}\text { Learning } \\
\text { Outcome }\end{array}$ & \multicolumn{1}{c|}{ Course topics that support the Learning Outcome } \\
\hline PIA & $\begin{array}{l}\text { This outcome is addressed in a number of topics. Students will develop a final project } \\
\text { proposal that particularly addresses this learning outcome }\end{array}$ \\
\hline PS & This outcome is achieved via student completion of their final projects. \\
\hline TC & $\begin{array}{l}\text { Students will have to complete and present their final project. This supports the techni- } \\
\text { cal communication learning outcome. }\end{array}$ \\
\hline IT & $\begin{array}{l}\text { Students learn new skills for developing websites and web-based applications using } \\
\text { HTML, DHTML and XML. Also, students complete a major project that deals with } \\
\text { issues on e-commerce. }\end{array}$ \\
\hline
\end{tabular}

\section{Conclusion}

This study showed how learning outcomes can be used as a basis to focus the IT curriculum and how students use a blended e-learning environment to facilitate their learning inside and outside the classroom. The $\mathrm{ZU}$ academic program model is driven by two sets of learning outcomes at both the college and university levels. All IT courses are developed to address College level and University learning outcomes. Master course syllabi are developed to show the course contributions to various learning outcomes. During their studies at $\mathrm{ZU}$, students are required to develop and present an electronic portfolio that includes samples of their most important learning experiences. Currently, the IT College is moving its courses to a web-based learning environment. Under this e-learning environment, the outcome-based academic model requires faculty members to shift their efforts from teaching or lecturing to facilitating student learning. Therefore, faculty need to reshape the course content and refocus their courses to clearly show all the steps needed to learn various concepts and skills. Moreover, technology is used as a tool to allow for the effective delivery of course content and also to facilitate discussion and communication without time constraints. Preliminary feedback from students shows that this learning environment is ideal for young female students from the Gulf who are shy; prefer limited interaction with male faculty and usually need more time to comprehend complex concepts in a second language. It is anticipated that using the outcome-based academic model will help foster an atmosphere of learning. Moreover, using a web based environment, the learning outcome model will help students take responsibility for their own learning, enhance their learning ability by using self-reflection, become active participants in the learning community and understand how to apply their knowledge in the real world.

\section{References}

Altenhofen, M. \& Schaper, J. (2002). Flexible instructional strategies for e-learning. Proceedings of the $35^{\text {th }}$ Annual Hawaii International Conference on System Sciences (HICSS'02).

Berge, Z. L. (1995). Facilitating computer conferencing: Recommendations from the field. Educational Technology,35(1), 22-30. 
Bodendorf, F., Schertler M. \& Cohen, E. (2005). Producing reusable web-based multimedia presentations. Interdisciplinary Journal of Knowledge and Learning Objects, 1, 127-142. Available at http://ijklo.org/Volume1/v1p127-142Bodendorf.pdf

Bouslama, F., Lansari, A., Al-Rawi, A. \& Abonamah, A. (2003) A novel outcome-based educational model and it is effect on students learning, curriculum development, and assessment. Journal of Information Technology Education (JITE), 2, 203-214. Available at http://jite.org/documents/Vol2/v2p203-21422.pdf

Cohen, E. B. \& Nycz, M. (2006) Learning objects and e-learning: an information science perspective. Interdisciplinary Journal of Knowledge and Learning Objects, 2, 23-34. Available at http://ijklo.org/Volume2/v2p023-034Cohen32.pdf

Furman, G., (1994) Outcome-based education and accountability. Education and Urban Society, 26 (4), 417-437.

Greater Expectation: A new vision for learning as a nation goes to college (2002), National Panel, Published by Association of American Colleges and Universities. http://www.aacu.org

Hodges, C. (2004). Designing to motivate: Motivational techniques to incorporate in e-learning experience. Journal of Interactive Online Learning, 2(3).

Internal report on self-assessment of Zayed University based on accreditation standards of the Middle States Commission on Higher Education (2004). Zayed University.

Kinshuk \& Young, A. (2003). Web-based asynchronous synchronous environment for online learning. Journal of the USDLA.

Koohang, A. \& Durante, A. (2003) Learner's perceptions toward the web-based distance learning activities/assignments portion of an undergraduate hybrid instructional model. Journal of Information Technology Education (JITE), 2, 105-113. Available at http://jite.org/documents/Vol2/v2p105-113-78.pdf

Linge, R (2003). The good, the bad, and the ridiculous: Putting a course online with Blackboard. The Consortium for Computing in Small Colleges.

Litiu, R. \& Prakash, A. (2000). Developing adaptive groupware applications using a mobile component framework. Proceedings of the ACM 2000 Conference on Computer Supported Cooperative Work (CSCW 2000), Philadelphia, PA, USA.

Muhlhauser, M. \& Trompler, C. (2002). Learning in the digital age: Paving a smooth path with digital lecture halls. Proc. HiCSS 35th Hawaii Intl. Conference, Waikola, HI, Jan. 7-12, 2001, IEEE CS press, Los Alamitos, CA, pp. 352-361.

Neubauer, M. \& Lobel, M. (2003). The learning by doing e-classroom. Journal of the USDLA, 17(2), 5-17.

Principe, J., Eulianno, N. \& Lefebvre, C. (2004). An interactive learning environment for adaptive systems instruction. Retrieved April 20, 2005 from http://www.cnel.ufl.edu/files/1023120351.pdf

Saunders, B., \& Quirke, P. (2002). Let my laptop lead the way: A Middle Eastern study. Educational Technology and Society, 5(1). ISSN 1436-4522.

Smith, M.\& Winking-Diaz, A. (2004). Increasing students' interactivity in an online course. The Journal of Interactive Online Learning, 2(3).

Tubaishat, A., Bhatti, A., \& El-Qawasmeh, E. (2006). ICT experiences in two different Middle Eastern universities. Journal of Issues in Informing Science and Information Technology, 3, 667-678. Available at http://informingscience.org/proceedings/InSITE2006/IISITTuba153.pdf

Zayed University. (2006). The academic program model. http://www.zu.ac.ae 


\section{Biographies}

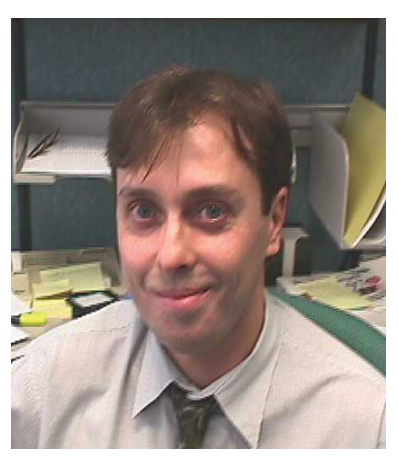

Azzedine Lansari received a $\mathrm{PhD}$ in Bioengineering from North Carolina State University in 1992. From 1992-1998, he was a senior researcher at Computer Sciences Corp. and MANTECH, Inc. He joined Zayed University in August 1998. Currently he is an assistant professor of Information Technology. His teaching interests include instructional technology and statistical modeling. His research interests include systems modeling, educational technology and curriculum design.

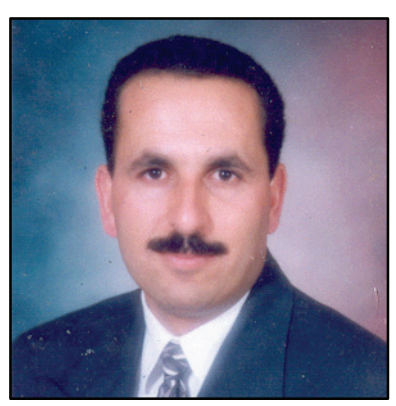

Abdallah Tubaishat is an assistant professor in the College of Information Technology at Zayed University, United Arab Emirates. He received his $\mathrm{PhD}$ degree in Software engineering from Illinois Institute of Technology, in 1994. Dr. Tubaishat has around eleven years of experience in teaching and research. His research interests include elearning, and software engineering. He has published a book with others entitled "Computer Skills", and has around eighteen Journal and conference publications.

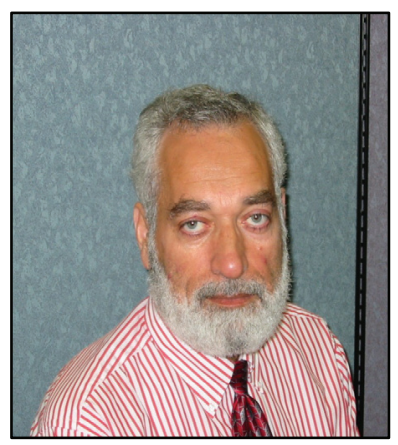

Akram Al-Rawi is a Professor of Computer Science at King Faisal University, Saudi Arabia. He has worked at several academic institutions of which the last three were Zayed University, University of Missouri-Columbia, and Columbia College, MO. His teaching interests include programming languages, networks, logic design, and computer architecture. His research interests include computer simulation, wireless, security, embedded systems, and curriculum design. He holds certifications in A+, Network + , Sun Certified Java Programmer, ICDL, i-Net+, Server+ and CCAI. 